\title{
Factor IXa inhibition contributes to the heparin effect
}

Citation for published version (APA):

Beguin, S., Dol, F., \& Hemker, H. C. (1991). Factor IXa inhibition contributes to the heparin effect. Thrombosis and Haemostasis, 66(3), 306-309. https://doi.org/10.1055/s-0038-1646412

Document status and date:

Published: 01/01/1991

DOI:

10.1055/s-0038-1646412

Document Version:

Publisher's PDF, also known as Version of record

\section{Please check the document version of this publication:}

- A submitted manuscript is the version of the article upon submission and before peer-review. There can be important differences between the submitted version and the official published version of record.

People interested in the research are advised to contact the author for the final version of the publication, or visit the DOI to the publisher's website.

- The final author version and the galley proof are versions of the publication after peer review.

- The final published version features the final layout of the paper including the volume, issue and page numbers.

Link to publication

\footnotetext{
General rights rights.

- You may freely distribute the URL identifying the publication in the public portal. please follow below link for the End User Agreement:

www.umlib.nl/taverne-license

Take down policy

If you believe that this document breaches copyright please contact us at:

repository@maastrichtuniversity.nl

providing details and we will investigate your claim.
}

Copyright and moral rights for the publications made accessible in the public portal are retained by the authors and/or other copyright owners and it is a condition of accessing publications that users recognise and abide by the legal requirements associated with these

- Users may download and print one copy of any publication from the public portal for the purpose of private study or research.

- You may not further distribute the material or use it for any profit-making activity or commercial gain

If the publication is distributed under the terms of Article $25 \mathrm{fa}$ of the Dutch Copyright Act, indicated by the "Taverne" license above, 


\title{
Factor IXa Inhibition Contributes to the Heparin Effect
}

\author{
Suzette Béguin, Frédérique Dol*, and H. Coenraad Hemker \\ From the Department of Biochemistry, University of Limburg, Maastricht, The Netherlands
}

\begin{abstract}
Summary
We investigated whether the inactivation of factor IX a contributes to the partial inhibition of thrombin formation that is observed at therapeutic concentrations of heparin. The action of standard unfractionated heparin $(0.05 \mathrm{U} / \mathrm{ml})$ on thrombin formation in the intrinsic system was compared to that of a mixture of dermatan sulfate (DS) and a synthetic pentasaccharide (PS). DS enhances the action of heparin cofactor II which inhibits thrombin only. PS specifically enhances the anti-factor Xa activity of antithrombin III (AT III). The concentrations of DS and PS were chosen so as to obtain equal anti-thrombin and anti-factor $\mathrm{Xa}$ activities as in $0.05 \mathrm{U} / \mathrm{ml}$ heparin. An extra inhibitory effect of heparin over the mixture is observed in situations where free factor IXa, not bound to factor VIII a and phospholipid, limits the rate of thrombin formation, notably in contact activated plasma. We conclude that the inactivation of free factor IXa by heparin contributes importantly to the inhibition of thrombin formation in the intrinsic system such as e.g. measured in the activated partial thromboplastin time.
\end{abstract}

\section{Introduction}

Heparin is known to catalyse the inactivation of the free serine proteases of blood coagulation by $\operatorname{AT~III~}(1,2)$. The amount of free thrombin that develops in clotting plasma is greatly reduced in the presence of heparin. This phenomenon can be either due to increased inactivation of the thrombin formed or to inhibition of prothrombin activation. This latter inhibition may be due to enhanced inactivation of activated factor $\mathrm{X}$ (factor $\mathrm{Xa}$ ) or to inhibition of factors upstream in the coagulation cascade. Factor $\mathrm{Xa}$ inactivation has been assumed to be particularly important with low molecular weight heparins because they inactivate isolated factor $\mathrm{Xa}$ more readily than thrombin (2). We have found that in a thromboplastin activated system unfractionated heparin and most low molecular weight heparins exert their effect almost exclusively via inhibition of thrombin $(3,4)$. A synthetic pentasaccharide (PS) identical to the main AT III binding site of heparin (5) and other very low molecular weight heparins do not or hardly affect thrombin breakdown but act via the inactivation of prothrombinase (3).

In the intrinsic (contact activated-)system, all heparins postpone and inhibit prothrombin conversion. McNeely and Griffith (6) found that complete inhibition of thrombin generation by $0.5 \mathrm{U} / \mathrm{ml}$ heparin is not due to inhibition of the contact system. The question that we ask here is whether factor IX a inactivation is (co-)responsible for the partial inhibition seen at partially inhibiting heparin concentrations such as they occur in patients. Whether heparin in the intrinsic system acts also via enhanced inactivation of factor IXa is important for the interpretation of

* Present address: Centre de Transfusion Sanguine, 31052 Toulouse Cedex, France

Correspondence to: Dr. H. C. Hemker, Department of Biochemistry, University of Limburg, P.O. Box 616, 6200 MD Maastricht, The Netherlands the effect of heparin on the activated partial thromboplastin time, the common test for estimating the effect of heparin administration in patients. We found earlier that the increase of the lag phase of thrombin formation in the intrinsic system is due to the inhibition of thrombin-mediated factor VIII activation and we surmised that the inhibition of prothrombin conversion could be due to the action of heparin-antithrombin III on factor IX a under these conditions (4). Our conclusions were based on calculation of prothrombin conversion rates from thrombin generation curves (7). Ofosu and his group came to similar conclusions by measuring prothrombin conversion by immunological methods $(8,9)$.

In the present study we compare the action of heparin to that of a mixture of PS and DS that has the same anti-thrombin and anti-factor Xa activity as the heparin. DS, that acts via heparin cofactor II, inhibits thrombin only (10), and the inhibitory action of PS is almost exclusively confined to factor $\mathrm{X}$ a (11). A mixture of PS and DS therefore can mimick the action of heparin with the exclusion of its effect on factor IX a. A larger effect of heparin compared to the DS-PS mixture thus can be used to spot the situations where factor IXa limits the rate of thrombin formation.

\section{Methods}

Heparin (4th international standard, $194 \mathrm{U} / \mathrm{mg}$ ), PS (batch IC 83.1423 at 800 International anti-factor X a U/mg) and DS (batch IC 87.374) were gifts of Dr. Jean Choay (Centre Choay, Gentilly, France). The plasma used was pooled platelet poor citrated plasma from 20 healthy donors, stored in $1 \mathrm{ml}$ portions at $-80^{\circ} \mathrm{C}$. It was defibrinated with reptilase before use. Isolated clotting factors were obtained according to the following references: factor IXa: 12; factor VIII: 13; thrombin: 14; human brain thromboplastin: 15 ; phospholipid ( $80 \%$ phosphatidyl choline, $20 \%$ phosphatidyl serine) 16. S2238 (HD-phe-pip-arg-p-nitrophenyl acetate, $2 \mathrm{HCl}$ ) was obtained from KabiVitrum, Stockholm, Sweden.

The anti-factor Xa activities of PS and standard heparin dissolved in normal plasma were determined according to refs. 17 and 18 .

Thrombin generation was assessed by spectrophotometric determination of the amidolytic activity on S2238 that develops in plasma after triggering thrombin formation. The $400 \mu \mathrm{l}$ reaction mixture contained $250 \mu \mathrm{l}$ of plasma and $85 \mu \mathrm{l}$ of buffer A (Tris- $\mathrm{HCl} 50 \mathrm{mM}, \mathrm{pH} 7.35,0.1 \mathrm{M}$ $\mathrm{NaCl}, 0.5 \%$ egg albumin) with the heparin or other inhibitors so as to obtain the final concentrations indicated and $65 \mu \mathrm{l}$ of the triggering solution.

The triggering solution consisted of $100 \mathrm{mM} \mathrm{CaCl}_{2}$ in buffer $\mathrm{A}$ with a) for the extrinsic pathway: human brain thromboplastin diluted so as to make the uninhibited, undefibrinated reaction mixture coagulate in $78-82 \mathrm{~s}, \mathrm{~b})$ for the intrinsic pathway: $15 \mu \mathrm{g} / \mathrm{ml}$ of kaolin plus $7.2 \mu \mathrm{M}$ of phospholipid, c) complete intrinsic factor $X$ activator or d) incomplete intrinsic factor $\mathrm{X}$ activator. The complete factor $\mathrm{X}$ activating enzyme complex ("complete tenase"), consisted of factor IXa (7.2 nM), factor VIII a $(10 \mathrm{U} / \mathrm{ml}$, i. e. $10 \mathrm{U} / \mathrm{ml}$ of factor VIII with $2.5 \mathrm{nM}$ thrombin added $2 \mathrm{~min}$ before use) and $7.2 \mu \mathrm{M}$ phospholipid. The incomplete factor $\mathrm{X}$ activator ("incomplete tenase") contained no factor VII a but was otherwise identical. Factors added in the course of the experiment were dissolved in $10 \mu \mathrm{l}$ of buffer $\mathrm{A}$ so as to obtain the final concentration indicated.

The amidolytic activity generated in the plasma mixtures was determined in $10 \mu \mathrm{l}$ aliquots that were transferred to $490 \mathrm{ml}$ buffer $\mathrm{A}$, at pH 7.9, containing $0.2 \mathrm{mM} \mathrm{S} 2238$ and $20 \mathrm{mM}$ EDTA. After $2 \mathrm{~min}, \mathrm{~S} 2238$ conversion was stopped by adding $300 \mu \mathrm{l}$ of concentrated acetic acid and the absorbancy at $405 \mathrm{~nm}$ was determined. For details on the method see ref. 7. 


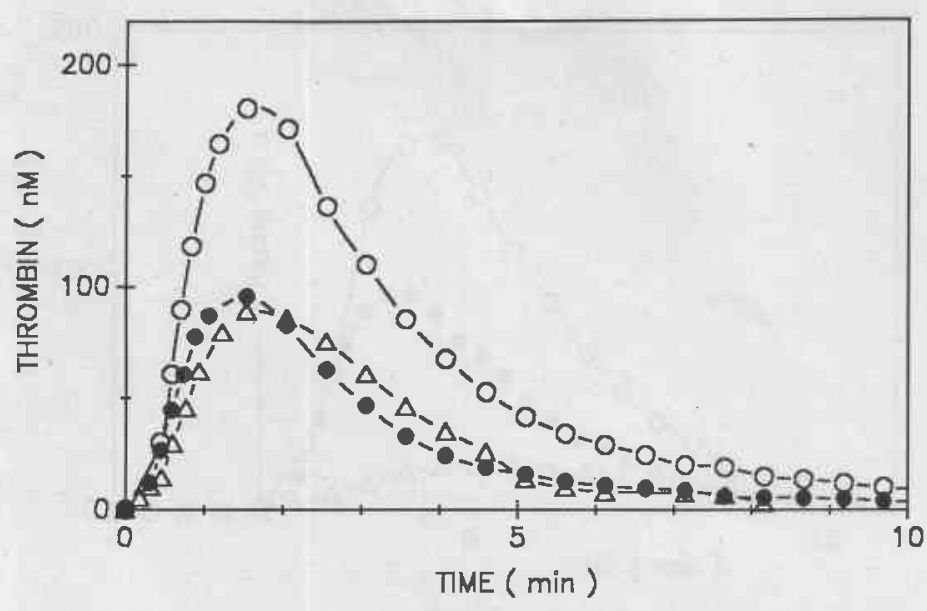

Fig. 1 Thrombin generation in thromboplastin activated plasma. Trigger: Diluted human brain thromboplastin as indicated under methods. O----O control; ----- DS $1.25 \mu \mathrm{g} / \mathrm{ml}-$ PS $0.06 \mu \mathrm{g} / \mathrm{ml} ; \triangle----\triangle$ heparin $0.05 \mathrm{U} / \mathrm{ml}$

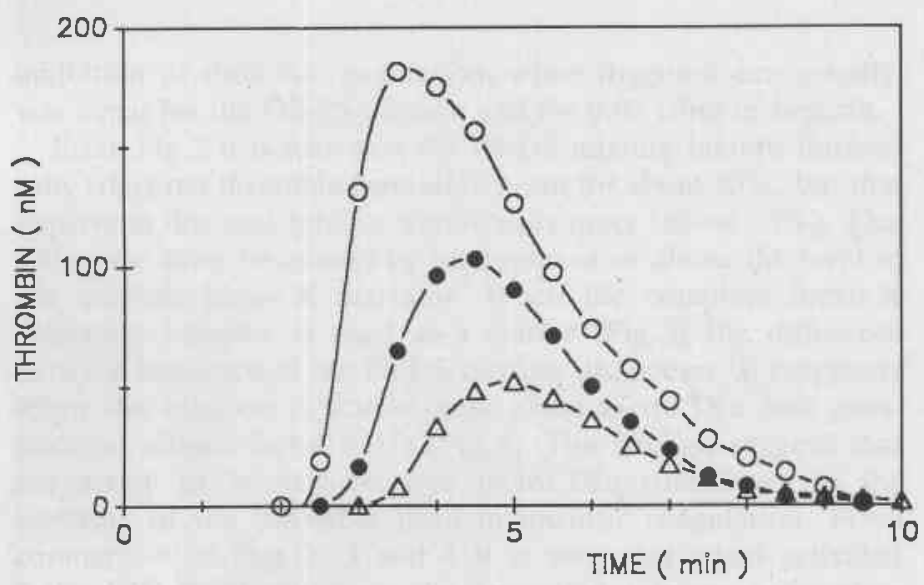

Fig. 2 Thrombin generation in contact activated plasma. Trigger: $\mathrm{Ca}^{2+}$, kaolin and phospholipid, as indicated under methods, symbols as in Fig. 1

At any time $t$, the amidolytic activity $\left(\underline{A}_{t}\right)$ represents the activity of thrombin $\left(\underline{T}_{t}\right)$ and the $\alpha_{2}$-macroglobulin-thrombin complex $\left(\underline{C}_{t}\right)$. This latter complex builds up during the reaction and causes final levels of amidolytic activity equivalent to about $50 \mathrm{nM}$ thrombin in the control and proportionally lower when heparin or DS favour the action of AT III or HC II. Because thrombin carries the physiologically important activities we prefer to give the time course of thrombin rather than that of amidolytic activity and therefore we subtracted $\underline{C}_{t}$ from $\underline{A}_{t}$ in order to obtain $\underline{T}_{t}$. Under our conditions, the $\alpha_{2}$-macroglobulin-thrombin complex has a molar activity on S2238 of 0.55 times that of thrombin (7). The concentration of the complex is obtained from an exact solution (see ref. 19) of the differential equations that govern the generation of thrombin $(\underline{T})$ and the $\alpha_{2}$-macroglobulin-thrombin complex $(\underline{C})$, viz:
$\mathrm{d} / \mathrm{d} t \underline{T}(t)=g(t)-\left(\underline{k}_{1}+\underline{k}_{2}\right) \cdot \underline{T}(t)$
$\mathrm{d} / \mathrm{d} \underline{\underline{t}} \underline{\underline{C}}(t)=\underline{k}_{2} \cdot \underline{T}(t)$

$$
\begin{aligned}
& {[\underline{T}(0)=0]} \\
& {[\underline{C}(0)=0]}
\end{aligned}
$$

$\underline{A}(t)=\underline{T}(t)+0.55 \cdot \underline{C}(\underline{t})$

Where $g(t)$ is the thrombin generation from prothrombin as a function of time; $\underline{k}_{1}$ the pseudo first order constant of the thrombin-antithrombin reaction and $k_{2}$ the pseudo first order reaction constant of the inactivation of thrombin by $\alpha_{2}$-macroglobulin; $\underline{k}_{2}$, was determined to be $0.23 \mathrm{~min}^{-1}$, in the absence as well as in the presence of heparin, PS and DS, by the method of ref. 7 .

For all practical purposes the solution can be visualized as a solution of the equations $\underline{C}_{t}+\Delta t=\underline{C}_{t}+\underline{k}_{2} \cdot \Delta t \cdot\left(\underline{A}_{t}-\underline{C}_{t}\right)$ and $\underline{C}_{0}=0$. The

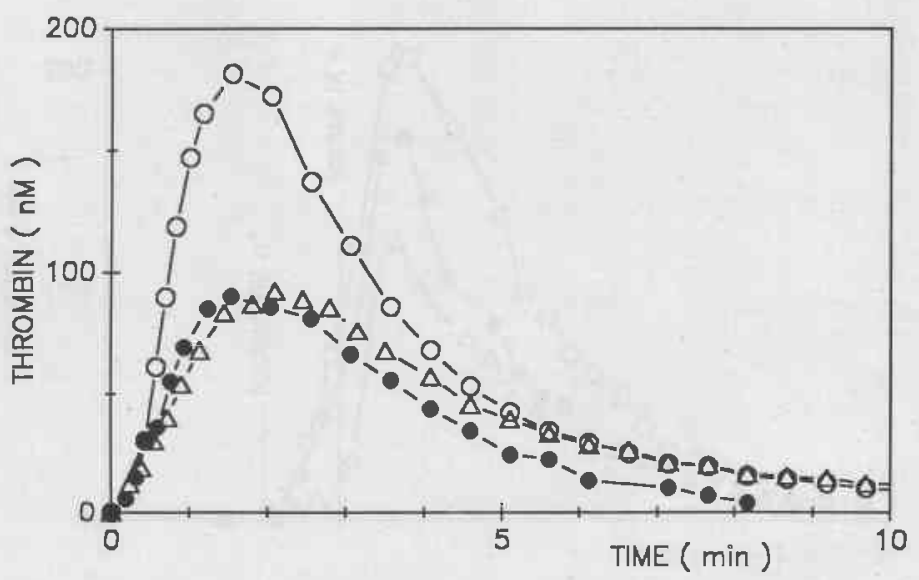

Fig. 3 Thrombin generation in plasma after triggering with complete tenase. Trigger: factor IXa $(1.2 \mathrm{nM})$, factor VIII a $(1.6 \mathrm{U} / \mathrm{ml})$, phospholipid $(1.2 \mu \mathrm{M})$ (final concentrations) and $\mathrm{Ca}^{2+}$ (see methods). Symbols as in Fig. 1

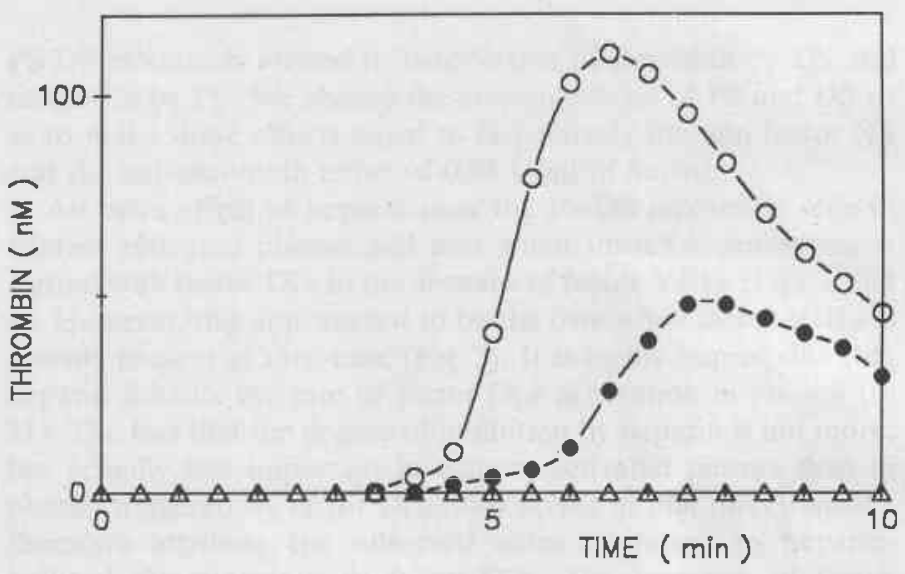

Fig. 4 Thrombin generation in plasma after triggering with incomplete tenase. Trigger: factor IXa, phospholipid and $\mathrm{Ca}^{2+}$. Final concentrations as in Fig. 3, symbols as in Fig. 1

calculation of free thrombin concentrations is not dependent upon any assumption except that of a pseudo-first order reaction of thrombin with $\alpha_{2}$-macroglobulin with the given rate constant. This is verified by the observation that the calculated thrombin concentrations eventually descend to the zero level.

\section{Results}

We used a heparin concentration of $0.05 \mathrm{U} / \mathrm{ml}(0.26 \mu \mathrm{g} / \mathrm{ml})$; this inhibits thromboplastin-induced thrombin formation about $50 \%$, mainly through increasing thrombin breakdown (4). In order to mimick the anti-factor $\mathrm{X}$ a effect of the heparin we added PS to obtain the same anti-factor $\mathrm{X}$ a activity as was present in the heparin solution, i.e. 0.05 anti-factor Xa-units $/ 1(0.06 \mu \mathrm{g} / \mathrm{ml})$. This has no anti-factor IX a action (11). From experiments on plasmas deficient in factor IX we found previously that factor IX activation contributes only negligibly to thromboplastin-induced thrombin formation under our experimental conditions (20). The inhibition caused by $0.05 \mathrm{U} / \mathrm{ml}$ of heparin, that is not caused by the PS added must therefore be due to thrombin inactivation. So we sought the concentration of DS that, in the presence of this amount of PS, would give $50 \%$ inhibition of the thrombin peak in the extrinsic system. This was $1.25 \mu \mathrm{g} / \mathrm{ml}$ (Fig. 1). In this way the 


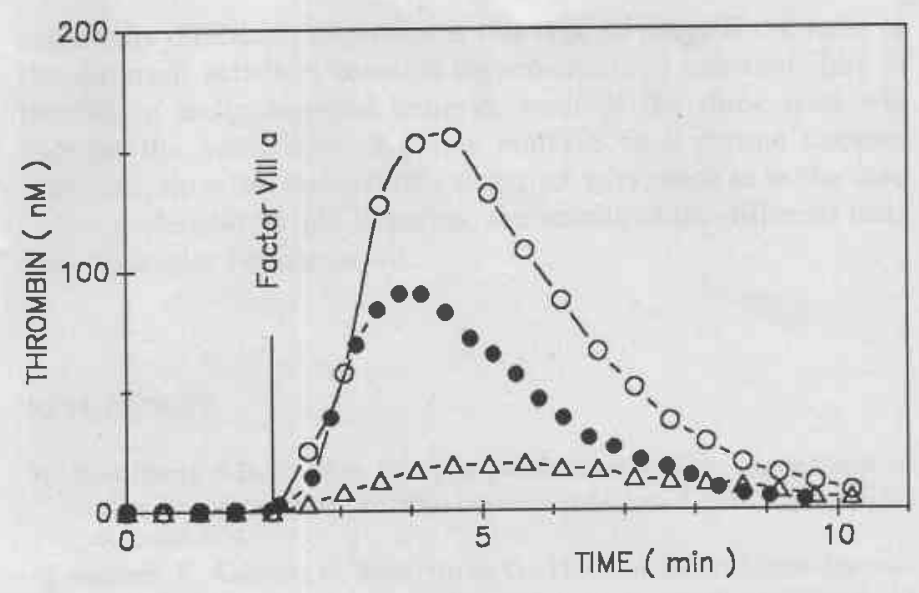

Fig. 5 Thrombin generation in plasma after triggering with incomplete tenase. Effect of addition of factor VIII a $(1.6 \mathrm{U} / \mathrm{ml})$ at $t=2$. Symbols as in Fig. 1. See text for experimental details

inhibition of thrombin generation, when triggered extrinsically, was equal for the DS-PS mixture and for $0.05 \mathrm{U} / \mathrm{ml}$ of heparin.

From Fig. 2 it is seen that the PS-DS mixture inhibits intrinsically triggered thrombin formation again for about $50 \%$, but that heparin in this case inhibits significantly more (about $75 \%$ ). This difference must be caused by inhibition at or above the level of the intrinsic factor $\mathrm{X}$ activator. When the complete factor $\mathrm{X}$ activating complex is used as a starter (Fig. 3) the difference between heparin and the PS/DS mixture disappears. It reappears when the reaction is started with alone factor IXa and phospholipid without factor VIII a (Fig. 4). This strongly suggests that the action of heparin on free factor IXa contributes to the lowering of the thrombin level in intrinsic coagulation. From comparison of Figs. 2, 3 and 4 it is seen that when activated factor VIII is absent from the triggering mixture a lag time appears in the control experiment. Both the PS-DS mixture and heparin prolong the lag time but heparin is more effective than PS-DS is. When factor VIII a is added during the lag time, thrombin generation starts immediately, independent of the inhibitor present (Fig.5). The amount of thrombin formed is, however, much higher with PS-DS than with heparin. It appears that the addition of factor VIII a switches on thrombin formation but that the actual amount of thrombin formed is dependent upon the concentration of a reactant that is specifically affected by heparin and not by PS-DS, i. e. factor IXa. That factor IX a is rate limiting under these circumstances is seen in the experiments presented in Fig. 6 where the addition of factor IXa after factor VIII a causes an increase of thrombin formation that is essentially equal in the presence of heparin and in the presence of the DS-PS mixture. (Note that the difference in peak height in Fig. 6 reflects the difference already existing at the moment of factor IX a addition.)

\section{Discussion}

It has been demonstrated that heparin, at a concentration of $0.5 \mathrm{U} / \mathrm{ml}$ completely inhibits factor $\mathrm{X}$ activation because no factor $\mathrm{X}$ is activated under these circumstances (6). We have investigated whether factor IX a inactivation contributes to the partial inhibition of thrombin generation seen at lower heparin concentrations. Inactivation of thrombin, factor $\mathrm{Xa}$ and/or factor IX a may contribute to this effect. The inhibitory effect of the

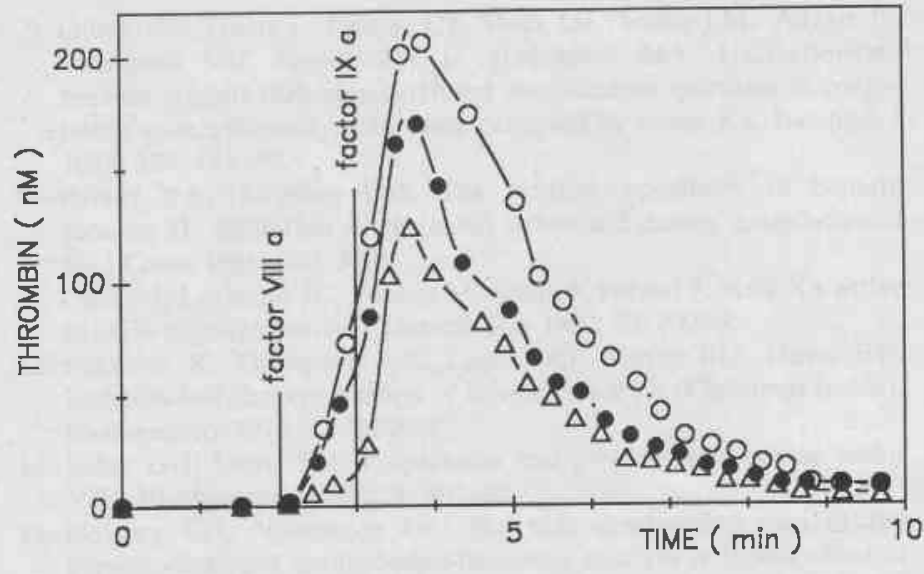

Fig. 6 Thrombin generation in plasma after triggering with incomplete tenase. Effect of addition of factor VIII a $(1.6 \mathrm{U} / \mathrm{ml})$ at $t=2$ and factor IXa $(1.2 \mathrm{nM})$ at $\mathbf{t}=3$. Symbols as in Fig. 1. See text for experimental details

PS-DS mixture is limited to inactivation of thrombin by DS and factor Xa by PS. We choose the concentrations of PS and DS so as to make these effects equal to respectively the anti-factor Xa and the anti-thrombin effect of $0.05 \mathrm{U} / \mathrm{ml}$ of heparin.

An extra effect of heparin over the PS-DS mixture is seen in contact activated plasma and also when thrombin formation is started with factor IX a in the absence of factor VIII a (Figs. 2 and 4). However, this appears not to be the case when factor VIII a is already present at zero time (Fig. 3). It is highly improbable that heparin inhibits the rate of factor IXa generation in plasma (6, 21). The fact that the degree of inhibition by heparin is not more, but actually less important in contact activated plasma than in plasma triggered by factor IXa, also points in that direction. We therefore attribute the observed extra inhibition to heparininduced disappearance of factor IXa. The presence of factor VIIIa (Fig. 3) prevents the extra inhibition, so heparin must inhibit free factor IXa, not bound to factor VIIIa and phospholipid. Thrombin formation triggered without added factor VIII a is not immediate as with complete tenase but shows a lag phase. Both in the presence and in the absence of inhibitors, the lag phase ends abruptly upon addition of factor VIIIa (Fig. 5), showing that factor VIII activation is compulsory. When factor VIII a is added after zero time, the resulting thrombin formation is much smaller when heparin is present in the medium than with the PS-DS mixture. This indicates that during the absence of factor VIII a heparin specifically causes inactivation of a rate limiting reactant. Factor IXa is the obvious candidate. Indeed when factor IXa is added after factor VIII a an equally high burst of thrombin formation is seen with the two inhibitors (Fig. 6). It seems that thrombin generation is switched on by the appearance of a threshold concentration of factor VIII a but that the peak height is determined by the amount of factor IX a available at the moment that factor VIII a appears. The effect of heparin on thrombin causes retardation of factor VIII activation and so prolongs the lag time. During the lag time heparin-AT III acts on the free factor IXa that is available. The concentration of factor IXa that is left at the moment of switch on, then determines the velocity of factor $\mathrm{X}$ activation and eventually the velocity of prothrombin conversion. It follows that the amount of thrombin generated in the aPTT is influenced by the antifactor IX a activity of heparin. The three current laboratory tests for measuring the heparin effect, i.e. aPTT, anti-thrombin activity and anti-factor $\mathrm{Xa}$ activity, therefore are susceptible to 
essentially different properties of this type of drug. If the ratio of the different activities remains (approximately) constant, like in batches of unfractionated heparin, each of the three tests will indicate the same level of active material in a plasma sample. However, then the ratios of the activities vary, such as in the case of low molecular weight heparins, the results of the different tests may no longer be compared.

\section{REFERENCES}

1. Rosenberg AD, Damus PS. The purification and the mechanism of action of human antithrombin-heparin cofactor. J Biol Chem 1973; 248: $6490-505$.

2. Holmer E, Kurachi K, Söderström G. The molecular weight dependence of the rate enhancing effect of heparin on the inhibition of thrombin, factor Xa, factor IXa, factor XIa, factor XIIa, or kallikrein by antithrombin. Biochem J 1981; 193: 395-400.

3. Hemker HC. The mode of action of heparin in plasma. In: XIth Congress Thrombosis and Haemostasis, Brussels. Verstraete M, Vermijlen J, Lynen HR, Arnout J (eds). Leuven University Press, Leuven 1987; pp 17-36.

4. Béguin S, Lindhout T, Hemker HC. The mode of action of heparin in plasma. Thromb Haemostas 1988; 60: 457-62.

5. Choay J, Petitou M, Lormeau JC, Sinay P, Casu BJ, Gatti G. Structure-activity relationship of heparin: a synthetic pentasaccharide with high affinity for antithrombin III and eliciting high anti-factor Xa activity. Biochem Biophys Res Commun 1983; 116: 492-9.

6. McNeely TB, Griffith MJ. The anticoagulant mechanism of action of heparin in contact-plasma: Inhibition of factor $\mathrm{X}$ activation. Blood 1985; 65: 1226-31.

7. Hemker HC, Willems G, Béguin S. A computer assisted method to obtain the prothrombin activation velocity in whole plasma independent of thrombin decay processes. Thromb Haemostas 1986; 56: 9-17.

8. Ofosu FA, Sié P, Modi GJ, Fernandez F, Buchanan MC, Blajchman MA, Boneu B, Hirsh J. The inhibition of thrombin-dependent positive-feedback reaction is critical to the expression of the anticoagulant effect of heparin. Biochem J 1987; 243 (2): 579-88.
9. Ofosu FA, Hirsh J, Esmon CT, Modi GJ, Smith LM, Anvari N, Buchanan MC, Fenton JW II, Blajchman MA. Unfractionated heparin inhibits thrombin-catalysed amplification reactions of coagulation more efficiently than those catalysed by factor Xa. Biochem $\mathrm{J}$ 1989; 257: 143-50.

10. Parker KA, Tollefsen DM. The protease specificity of heparin cofactor II. Inhibition of thrombin generated during coagulation. J Biol Chem 1985; 260: 3501.

11. Choay J, Lormeau JC, Petitou M, Sinaÿ P, Fareed J. Anti Xa active heparin oligosaccharides. Thromb Res 1980; 18: 573-8.

12. Fujikawa K, Thompson AR, Legaz ME, Meyer RG, Davic EW. Isolation and characterization of bovine factor IX (Christmas factor). Biochemistry 1973; 12: 4938-45.

13. Vehar GH, Davie EW. Preparation and properties of bovine factor VIII. Biochemistry 1980; 19: 401-10.

14. Pletcher $\mathrm{CH}$, Nelsestuen GI. The rate determining step of the heparin-catalyzed antithrombin-thrombin reaction is independent of thrombin. J Biol Chem 1982; 257: 5342-5.

15. Owren PA, Aas K. The control of dicoumarol therapy and the quantitative determination of prothrombin and proconvertin. Scand $\mathrm{J}$ Clin Lab Invest 1951; 3: 201-18.

16. Rosing J, Tans G, Govers-Riemslag JWP, Zwaal RFA, Hemker HC. The role of phospholipids and factor $\mathrm{Va}$ in the prothrombinase complex. J Biol Chem 1980; 255: 274-83.

17. Teien AN, Lie M, Abildgaard U. Assay of heparin in plasma using a chromogenic substrate for activated factor X. Thromb Res 1976; 8: 413-6.

18. Teien AN, Lie M. Evaluation of an amidolytic heparin assay method: Increased sensitivity by adding purified antithrombin III. Thromb Res 1977; 10: 399-410.

19. Willems GM, Hemker HC. Mathematical analysis of the thrombin generation curve. Thromb Haemostas 1986; 56: 15-7.

20. Ma Xi, Béguin S, Hemker HC. Importance of factor IX-dependent prothrombinase formation - the Josso pathway - in clotting plasma. Haemostasis 1989; 19: 301-308.

21. Colman RW, Scott CF, Pixley RA, De La Cadena RA. Effect of heparin on the inhibition of the contact factor enzymes. Ann NY Acad Sci 1989; 556: 95-103.

Received November 21, 1990 Accepted after revision March 11, 1991 